\title{
Hendra Virus Disease: A Highly Infectious Emerging Anthropozoonosis
}

\author{
Mahendra Pal* \\ Professor, Narayan Consultancy on Veterinary Public Health and Microbiology, \\ Aangan, Gujarat, India \\ *Corresponding Author: Mahendra Pal, Professor, Narayan Consultancy on \\ Veterinary Public Health and Microbiology, Aangan, Gujarat, India.
}

Received: December 15, 2020

Published: January 22, 2021

(C) All rights are reserved by Mahendra Pal.

DOI: 10.31080/ASMI.2020.04.0762

Anthropozoonosis is an infectious disease that is transmitted from animals to humans [1]. There are a number of anthropozoonotic diseases that are caused by viruses ( bird flu, cowpox, contagious ecthyma, herpes simiae, Margburg disease, monkey pox, rabies, swine flu), bacteria (anthrax, brucellosis, cat scratch disease, glanders, leptospirosis), prion (bovine spongiform encephalopathy), fungi (Microsporum canis infection, Trichophyton verrucosum infection), protozoa (sarcocystosis, toxoplasmosis), helminthes (gnathostomiasis, trichinosis), and ectoparasites (linguatuliasis, scabies) [2-4]. These diseases affect both sexes, and all age groups, and may occur in sporadic and epidemic form, and are reported from developing as well as developed countries of the world [1].

Emerging zoonoses, which involve multiple etiologies, are important causes of significant morbidity and mortality in humans and also in animals [1,5]. Several emerging zoonoses, such as Nipha virus disease, West Nile fever, Hendra virus disease, avian influenza, Hantavirus infection, swine flu, Ebola disease, severe acute respiratory syndrome, and others were reported in the last few decades [6,7]. These zoonoses are transmitted through various modes that include direct contact, inhalation, vector, and others [1]. Among these, Hendra virus disease is a life threatening highly infectious emerging viral zoonosis that was first described in Hendra, a suburb of the Brisbane, Queensland, Australia during September 1994 [1]. The disease is caused by Hendra virus, a highly pathogenic Paramyxovirus [1]. Hendra virus belongs to the genus Henipa virus, and family Paramyxoviridae [8]. It is a pleomorphic, non-segmented negative-stranded RNA virus [9]. The virus is susceptible to heat, soaps, detergents, and several disinfectants like chlorhexidine, iodophors, and hypochlorite but is resistant to alkalis and acids [8].The fruit bats belonging to the genus Pteropus serve as the natural reservoir of the virus $[1,10]$.

Humans can acquire the infection from close contact with diseased horse. Contact with infected blood, body fluids, tissues, excretions can also cause infection. Veterinarians may get infection during the act of performing necropsy of horse [1]. Horse can be infected by consuming the feed contaminated by the virus [1].The infection is transmitted from the fruit bat to horse, horse to horse, and horse to humans [9]. Hitherto, there is no evidence of transmission of infection from human to human. It is important to mention that Hendra virus is transferred from bats to horses, before spreading to humans [9]. Horse to horse transmission can occur through close contact [1].

The natural infection has been described in humans and horses [1]. Subclinical infection is detected in dogs [8].The virus is isolated from the fruit bats [10]. Experimental infection is produced in African Green monkeys, pigs, cats, hamsters, Guinea pigs, and ferrets [8]. However, no infection could be produced experimentally in the rabbits, rats, and chickens [8].

Hendra virus disease is an emerging zoonosis of horses and humans in Australia [8].The first outbreak of Hendra virus disease that occurred in 1994, involved 21 stabled racehorses and two human cases [9]. The infection is highly fatal in humans and equines [1]. The disease poses a major concern to the horse industry in Australia. The veterinarian, veterinary assistant, equine breeder, and animal attendant are a greater risk of acquiring the infection $[1,11]$.

The symptoms of Hendra virus disease in humans occur 5 to 21 days after the exposure [8]. The disease in humans is manifested with a variety of clinical symptoms, such as fever, headache, drowsiness, fatigue, myalgia, dry cough, sore throat, pneumonia, cervical lymphadenopathy, vomiting, neck stiffness, vertigo, ataxia, seizures, coma, and death [8].

The incubation period disease in horses may range from 3 to 15 days. The affected animals may exhibits fever, anorexia, depression, uneasiness, sweating, nasal discharge, respiratory distress, subcutaneous oedema, tremors, ataxia, locked jaw, blindness, head tilt, and facial paralysis [8]. The fatality rate is high in diseased horses [1].

The clinical symptoms are not very characteristic to warrant the tentative diagnosis. Therefore, the laboratory help that include vi- 
rus isolation, antigen detection, immunohistochemistry, and PCR can be applied to confirm the diagnosis of Hendra virus $[1,8]$. Cross reactions have been observed between Hendra virus and Nipha virus in immunological assays [8].The laboratory with biosafety level 4 (BSL-4) facilities is very necessary for the isolation of virus from the clinical samples [8].

Currently, no specific antiviral drug is available for the management of Hendra virus infection in humans and horses. Protective wears, such as respirator, impervious gloves, splash proof apron, impervious boots, and face shield for eyes is very essential for the veterinarian during the examination of sick animal or performing autopsy of horse $[1,8]$. Other preventive measures include quarantine of the infected horse, good hygienic practices, avoiding close exposure with diseased horses and their discharges, and health education [1]. It is mentioned that immunization is considered as main alternative for preventing Hendra virus infection in horses [9]. Equivac $\mathrm{HeV}$ is subunit vaccine that has been employed to prevent the infection in horses [9]. It is emphasized to undertake studies on the pathogenesis, epidemiology, and chemotherapy of Hendra virus disease.

\section{Acknowledgements}

The author is very grateful to Prof. Dr. R.K. Narayan for going through the manuscript and giving his suggestions. Thanks are also due to Anubha Priyabandhu for computer help.

\section{Bibliography}

1. Pal M. “Zoonoses". 2nd Edition. Saatyam Publishers, Jaipur, India (2007).

2. Pal M. "Contagious ecthyma: An infectious emerging viral anthropozoonotic disease". Acta Scientific Microbiology 1 (2018a): 1.

3. Pal M. "Anthrax: A neglected bacterial zoonosis of major public health concern". Acta Scientific Microbiology 1 (2018b): 78-79.

4. Pal M. "Growing significance of cat scratch disese as an emerging zoonosis". Acta Scientific Microbiology 1 (2018c): 68-69.
5. Pal M. "Public health concern due to emerging and re-emerging zoonoses". International Journal of Livestock Research 3 (2013): 56-62.

6. Pal M., et al. "Ebola haemorrahgic fever: An emerging highly contagious and fatal viral zoonosis". Ethiopian International Journal of Multidisciplinary Research 2 (2014): 1-2.

7. Pal M. "Severe acute respiratory syndrome: A newly recognized viral zoonosis of public health concern". Acta Scientific Microbiology 1 (2018d): 1.

8. CFSPH. Hendra virus. The Center of Food Security and Public Health, Iowa State University, USA (2015): 1-9.

9. Khusro A., et al. "Hendra virus infection in horses: A review on emerging mystery Paramyxovirus". Journal of Equine Veterinary Science (2020).

10. Haplin K., et al. "Isolation of Hendra virus from pteropid bats: a natural reservoir of Hendra virus". Journal of General Virology 81 (2000): 1927-1932.

11. Hanna J., et al. "Hendra virus infection in a veterinarian". Medical Journal of Australia 185 (2006): 562-564.

\section{Assets from publication with us}

- Prompt Acknowledgement after receiving the article

- Thorough Double blinded peer review

- Rapid Publication

- Issue of Publication Certificate

- High visibility of your Published work

Website: www.actascientific.com/

Submit Article: www.actascientific.com/submission.php

Email us: editor@actascientific.com

Contact us: +919182824667 